\title{
MODE CHOICE BEHAVIOR FOR GROUND ACCESS TO AIRPORTS: A CASE OF ISTANBUL ATATÜRK INTERNATIONAL AIRPORT (IST) AND SABIHA GOKCEN INTERNATIONAL AIRPORT (SAW)
}

Gürkan GÜNAY*, Department of Civil Engineering, Dogus University, Turkey, ggunay@dogus.edu.tr, Tel: 444-7997

(iD) https://orcid.org/0000-0003-0597-1511)

Received 11.02.2020, Accepted: 09.09.2020

*Corresponding author

Research Article

DOI: $10.22531 /$ muglajsci.688018

\section{Abstract}

Accessing airports has been a problem for passengers due to traffic congestion in cities. Thus, in order to catch the flights on time, passengers consider many factors to choose the transportation mode for airport access. Some of the factors are covariates, and they can be listed as age of the passenger, number of luggage carried, travel cost and travel time to the airport, group size of the passengers, and reliability of access modes. These covariates, may differ for each airport; and hence, in this paper, we investigated the differences of these covariates between Istanbul Ataturk International Airport (IST) and Istanbul Sabiha Gokcen International Airport (SAW). Analysis of Variance (ANOVA) and post-hoc tests were conducted to investigate the covariates that affect the mode choice to access IST and SAW. The results indicated that these two airports have differences in terms of the effect of these selected six covariates on airport access mode choice. Reliability of the modes, travel time, travel cost, age of the passenger and traveling group size affected the mode choice to access IST. On the other hand, only reliability of the modes, travel time and travel cost had effects on airport access mode choice for SAW. Based on the analysis, some recommendations for the decision makers were also provided.

Keywords: Mode choice behavior, access to airports, ANOVA

\section{HAVALIMMANLARINA ERIŞSIM İÇİN TÜREL SEÇIM DAVRANIŞI: İSTANBUL ATATÜRK ULUSLARARASI HAVALIMMANI (IST) VE SABİHA GÖKÇEN ULUSLARARASI HAVALIMANI (SAW) ÖRNEĞ́̇}

\section{Özet}

Şehirlerde trafik sıkışıklığından dolayı havalimanlarına erişim bir sorun haline gelmiştir. Bu yüzden, yolcular havalimanlarına erişimdeki ulaşım türü seçimlerinde uçuşlarını kaçırmamak adına birçok faktörü değerlendirmektedir. Bu faktörlerin bazısı yolcunun yaşı, beraber seyahat ettiği kişi sayısı, bagaj sayısı, havalimanına yaptığı seyahatin maliyeti ve süresi ile ulaşım türünün güvenirliğidir. Bu faktörler havalimanları arasında farklılık gösterebilir. Dolayısıyla, bu çalışmada, sözü edilen faktörlerin farkı İstanbul Atatürk Uluslararası Havalimanı (IST) ve İstanbul Sabiha Gökçen Uluslararası Havalimanı (SAW) arasında incelenmiştir. Bu inceleme, Varyans Analizi (ANOVA) ve ona ait post-hoc testleri ile yapılmıştır. Sonuçlara göre, havalimanına erişimde kullanılan ulaşım türlerinin seçimini etkileyen faktörler hususunda bu iki havalimanı arasında farklılıklar mevcuttur. Ulaşım türlerinin güvenirliliğinin, seyahat süresinin, seyahat maliyetinin, yolcunun yaşının ve yolcuyla beraber seyahat eden kişi sayısının, IST'a erişim için ulaşım tür seçiminde etkili olduğu ortaya çıkmıştır. Ancak SAW'a erişim için sadece ulaşım türü güvenirliliği, seyahat süresi ve seyahat maliyeti tür seçiminde etkin olmuştur. Analizin sonuçlarına bağlı olarak, karar verici merciiler için bazı tavsiyelerde bulunulmuştur. Anahtar Kelimeler: Ulaşım tür seçimi davranışı, havalimanlarına erişim, ANOVA

Cite

Günay, G., (2020). “Mode Choice Behavior for Ground Access to Airports: A Case Study of Istanbul Ataturk International Airport (IST) and Sabiha Gokcen International Airport (SAW)", Mugla Journal of Science and Technology, 6(2), 28-35.

\section{Introduction}

There are many continuous variables, or covariates, affecting the access mode choice for an airport such as age of the passenger, travelling group size, time allowed between the departure time to the airport and flight time, number of luggage each passenger is carrying, travel cost to airport and travel time to airport. Lots of research was made for many of these factors [1-16]. In many cases, travelers are more influenced by travel time rather than the cost of the mode of access in order to avoid larger costs if they miss their flights. Harvey [1] has determined that with travel time becomes more important for travelers as it increases. Akar [2] stated 
that most of the results in the literature indicated that for alternative modes to compete with autos, their travel time should be much shorter. For busses, Tam et al., [3] determined that for busses to become more attractive, their travel time reliabilities should be improved. Similarly, Choo et al., [4] found that choice of access mode is directly related to travel time rather than its cost. Another study conducted by Alhussein [5] for King Khaled International Airport (KKIA) discovered that access time seemed to be more important than access cost due to the flight schedules. In addition, Yang and Liao [6] also revealed that business travelers valued time more than non-business travelers did. In other studies, Jou et al. [7] separated travel time into two components as in-vehicle and out-of-vehicle travel times; and concluded that those two factors affected passengers' mode choice for airport access in Taoyuan, Taiwan. Similarly, Monteiro and Hansen [8] also divided the travel time into two as waiting time and access time; and found both variables to be significant in passengers' joint choice of airport and access mode. Hess and Polak [9] reported that travel time to airport affected the airline, airport and access mode joint choice as well. These studies show the importance of the travel time on airport access mode choice.

Trip cost to airport is another important factor that can easily separate the type of traveler as business or nonbusiness traveler based on their response and sensitivity to the mode choice of access. Harvey [1] presented that cost is less important for business travelers than it is for non-business travelers. Nonbusiness travelers become less sensitive to cost with increasing income, except on long-haul flights. Similar argument was also made by Pels and Nijkamp [10] that cost was not as critical as travel time for business passengers. Furthermore, Tam et al., [3] determined that business travelers are willing to pay more for fast and reliable airport access due to the fact that missing a booked flight will mostly cost more than just the price of the ticket.

Reliability of the modes of access is one of the key factors that affects mode choice of the passengers. Passengers having to use an unreliable mode of access will have larger safety margins which is defined in the study of Koster et al., [11], as the difference between the preferred arrival time and the expected arrival time at the airports. Tam et al., [3] determined that large groups of passengers tend to allow a larger safety margin. Gokasar and Gunay [12] found that passengers would leave a higher travel margin if they would be traveling with either public transit or taxi to Ataturk International Airport in Istanbul.

Age is another important factor changing both the physical and psychological attributes of the passenger thus affecting airport access mode choice. Koster et al., [6] has found out that passengers between ages of 30 and 49 are more likely to choose alternative modes of transportation compared to younger and older travelers which is a contradiction to previous studies that were made by Gupta et al., [13] and Tam et al., [3], which determined in their research that younger passengers prefer to use the lower cost alternatives. In another study, Choo et al. [4] explained that increase in age lowered the probability of choosing automobile over subway.

Other covariates that influence the mobility, thus also the decision of mode, are the size of the group of passengers and the number of luggage carried. Tam et al., [3] determined that an increase of the group size has a positive effect on the utilization of taxi or private car due to the fixed per-person nature of cost of airport express services and busses. Further, parallel to that, Budd et al., [14] revealed that lone travelers preferred public transport for airport access. Harvey [1] has found out that carrying luggage has a large influence on the decision making of non-business travelers and severely reduces the attractiveness of transit access modes. Similarly, Alhussein [5] revealed that one unit increase in luggage resulted in an increase for the preference of private car usage. Further, Tsamboulas and Nikoleris [15] discussed that baggage carrying passengers may even consider paying more for a mode that would provide comfort with the luggages. Budd et al. [16] also argued that leisure passengers would avoid public transport since they would be carrying more than a single luggage.

This paper investigates covariates that affect the mode choice to access two different airports, namely Istanbul Ataturk International Airport (IST) and Istanbul Sabiha Gokcen International Airport (SAW). It should be noted that in 2018, Istanbul Airport was opened. It replaced IST, except cargo and general aviation flights. It was aimed to provide a comparison of two airports in a city in terms of ground access mode choice, even though IST stopped passenger flight operations. IST abbreviation is now used for Istanbul Airport in aviation, but it was previously used for Istanbul Ataturk International Airport; so, IST is used to abbreviate the latter airport in this work.

The contributions of this study can be listed as the following:

- To understand if covariates affecting airport access mode choice had similar effects at IST and SAW. The reason is that while a certain covariate may influence mode choice to access IST, it may not have that effect for SAW.

- Investigation was done using analysis of variance (ANOVA) and its related post-hoc tests. In this work, the total number of investigated variables was six, and they are the following: Age of the passenger (Age), travelling group size (Group Size), time allowed between the departure time to the airport and flight time (Margin), number of luggage each passenger is carrying (Number of Luggage), travel cost to the airport (Cost) and travel time to the airport (Travel Time). Post-hoc tests would show 
which modes were similar in terms a specific covariate which affected the airport access mode choice.

\section{Input Data}

As of 2015, IST was the primary airport of Istanbul and SAW as the secondary. IST was opened in 1953, and SAW started operating in 2001. IST was the domestic and international hub for Turkish Airlines and SAW was, and still is, the hub for Pegasus Airlines, a low-cost carrier. SAW also hosts for numerous Turkish Airlines flights, both domestic and international.

In 2015, IST handled 41.9 million international and 19.3 million domestic passengers, more than its annual capacity (25.5 million international and 12.8 million domestic passengers per year) (General Directorate of State Airports Authority of Turkey, 2016). These statistics for SAW are 9.6 million and 18.5 million for international and domestic passengers. It can be seen that IST has a little more domestic traffic than SAW has.

IST is located at the west of central Istanbul, in Bakırköy district of the European side of the city. The distance between IST and Beyoğlu district, which is the city center, is $22 \mathrm{~km}$. On the other hand, SAW is located at the opposite end of Istanbul in Asian side, in Pendik district with a distance of $42 \mathrm{~km}$ to city center.

Surveys were conducted with passengers at both IST and SAW to collect data. The data collection was made near check-in kiosks in both domestic and international departures during four days in January 2015. On each day, two sessions were held, between 10:00-13:00 and 17:00-20:00. Number of collected responses were 546 at IST and 251 at SAW. No missing data was included. Reason for the higher number of responses at IST can be associated with the number of passengers handled at both airports: Number of annual passengers at IST was more than two times of SAW in 2015. Respondents were both domestic and international Turkish travelers; and were selected using convenience sampling method.

Respondents were asked about demographics such as age, gender, education level and automobile ownership. Besides, there were questions also about their mode choices to access the airport on the day of interview, costs and travel times of their trips to the airport, number of luggage they were carrying, number of passengers they are traveling with, and amount of time they let before their flight to complete their access trips and formalities at the airport.

Some demographics of the passengers are given in Table 1. It can be observed that most of the respondents travel domestically, were men, graduated from high school and owned an automobile. The distributions of the categories across these demographics were more evenly at IST compared to SAW, even though there were notable differences.
Table 1: Demographics of passengers.

\begin{tabular}{ccccc}
\hline & \multicolumn{3}{c}{ IST } & \multicolumn{3}{c}{ SAW } \\
\cline { 2 - 5 } & Frequency & \multicolumn{5}{c}{ Frequency } & $\%$ \\
\cline { 2 - 5 } Destination \\
Domestic & 349 & 63.9 & 200 & 79.7 \\
International & 197 & 36.1 & 51 & 20.3 \\
Total & 546 & 100.0 & 251 & 100.0 \\
\cline { 2 - 5 } Men & \multicolumn{5}{c}{ Gender } \\
\cline { 2 - 5 } Women & 353 & 64.7 & 180 & 71.7 \\
Total & 193 & 35.3 & 71 & 28.3 \\
& 546 & 100.0 & 251 & 100.0 \\
\cline { 2 - 5 } Elementary & 57 & 10.4 & 13 & 5.2 \\
School & 124 & 22.7 & 31 & 12.4 \\
High School & 301 & 55.1 & 170 & 67.7 \\
Undergraduate & 50 & 9.2 & 32 & 12.7 \\
Master & 14 & 2.6 & 5 & 2.0 \\
PhD & 546 & 100.0 & 251 & 100.0 \\
Total & \multicolumn{5}{c}{ Automobile Ownership } \\
\cline { 2 - 5 } & 55.1 & 144 & 57.4 \\
Yes & 301 & 55.1 & 107 & 42.6 \\
No & 245 & 44.9 & 107 \\
Total & 546 & 100.0 & 251 & 100.0 \\
\hline
\end{tabular}

Five modes of transportation to access airports were considered: Auto, drop-off, public transit (PT), shuttle and taxi. If the passenger drives on his/her own, then the mode is auto. The mode is drop-off if someone takes the passenger to the airport using auto.

In data, mode shares for IST and SAW were revealed to be different from each other. As it can be seen in Table 2 , shuttle mode was omitted from the analysis for IST because its share was only $4.2 \%$ before the omission; hence, it was considered that making inferences with such a small amount of data would be inappropriate. However, share of shuttle for SAW was the highest with $29.5 \%$. Furthermore, public transit means are also different, IST is connected via semi-rapid transit rail to city center while public buses serve to SAW. The effect of rail system at IST can be easily observed, as its share is the highest with $40.8 \%$. Auto and drop-off shares are similar between airports while taxi is lower for SAW. That can be due to the longer distance of SAW to the city center.

Table 2: Mode shares in data for IST and SAW.

\begin{tabular}{cccc}
\hline IST Modes & $\%$ & SAW Modes & $\%$ \\
\hline Auto & 12.8 & Auto & 10.4 \\
Drop-off & 15.8 & Drop-off & 15.1 \\
Public Transit & 40.8 & Public Transit & 23.5 \\
Taxi & 30.6 & Shuttle & 29.5 \\
Total & 100.0 & Taxi & 21.5 \\
& & Total & 100.0 \\
\hline
\end{tabular}

Table 3 shows the means and standard deviations of the covariates used in this research. It can be seen that average ages were similar at both airports. However, average group size was higher at IST than SAW. Average group size at SAW was less than 1, which meant most passengers were lone travelers, no one accompanied 
them. Passengers let a higher safety travel time margin for IST than SAW. This could be because IST hosts more international travelers than SAW do. A passenger should arrive at least two or three hours before an international flight. On the other hand, that time can be smaller for domestic flights, such as one hour. It should be also noted that percentage of the international flights in data was higher at IST than SAW. Further, standard deviation of margin was also higher at IST, which indicated a higher variance. Number of luggage had similar average values at both airports, as well as their standard deviations. Average cost in Turkish Lira (TL) to access IST is greater than of SAW. This could be because of the direct rail transit connection to IST. As it was also said previously, share of public transit, the cheapest mode, was higher for IST. Finally, Travel Time to access SAW was higher, and this could be expected because SAW is further to city center than IST.

Table 3. Means and standard deviations of covariates

\begin{tabular}{lcccc}
\hline & \multicolumn{2}{c}{ IST } & \multicolumn{2}{c}{ SAW } \\
\cline { 2 - 5 } & Mean & $\begin{array}{l}\text { Standard } \\
\text { Deviation }\end{array}$ & Mean & $\begin{array}{l}\text { Standard } \\
\text { Deviation }\end{array}$ \\
\cline { 2 - 5 } Age & 34.568 & 12.161 & 32.944 & 10.841 \\
$\begin{array}{l}\text { Group } \\
\text { Size }\end{array}$ & 1.132 & 1.708 & 0.782 & 1.034 \\
$\begin{array}{l}\text { Margin } \\
\text { Number } \\
\text { of }\end{array}$ & 191.832 & 94.444 & 170.060 & 56.774 \\
$\begin{array}{l}\text { Luggage } \\
\text { Cost (TL) }\end{array}$ & 15.787 & 24.142 & 26.756 & 27.150 \\
$\begin{array}{l}\text { Travel } \\
\text { Time }\end{array}$ & 57.176 & 32.321 & 73.048 & 35.749 \\
\hline
\end{tabular}

\section{Methodology}

Analysis of Variance (ANOVA) and its related post-hoc tests were used for the analyses. First, with ANOVA, it was aimed to investigate if a given covariate has statistically equal means across the transportation modes used to access the airports. If at least one of the means is not equal to the other modes for a certain variable, then post-hoc tests were conducted to see which modes were equal to each other with respect to that covariate. Gunay and Gokasar [12] used ANOVA to understand if a certain covariate really affected the ground access mode choice. If so, then that covariate was inserted in the Multinomial Logit model they developed to model the behavior of passengers. However, in this work, the aim was only the comparison of access modes serving IST and SAW in terms of these covariates using ANOVA and its post-hoc tests. With the post-hoc tests, it was aimed to understand which mode types were similar to each other in terms of each covariate.

For an observation $j$ in the ith category, the value of a covariate $X$ can be expressed as the following; given by Walpole et al. [17]:

$$
X_{i j}=\mu+\alpha_{i}+\epsilon_{i j}
$$

, where $\mu$ is the grand mean (mean of all means of categories) $\alpha_{i}$ is the effect resulting from category $i$ and $\epsilon_{i j}$ is the error term.

ANOVA is used to observe if the means of a certain continuous variable are statistically equal to each other across the categories of a categorical variable. The null hypothesis for ANOVA is given by [17];

$$
H_{0}: \mu_{1}=\mu_{2}=\cdots=\mu_{k}
$$

, where $k$ is the index of categories and $\mu_{k}$ is the mean of a covariate for the $k$ th category. This null hypothesis is tested with $\alpha \%$ level of significance. If the null hypothesis is rejected, then it is concluded that at least two of the means are statistically different. Thus, it is continued with post-hoc tests to understand which categories have different means.

Nevertheless, homogeneity of variances for the covariate had to be checked using Levene's test before choosing which post-hoc test to apply. This test is applied to understand if the covariate has homogenous variances across the categories. The null hypothesis for this test is [17];

$$
H_{0}: \sigma_{1}^{2}=\sigma_{2}^{2}=\cdots=\sigma_{k}^{2}
$$

, where $\sigma_{k}^{2}$ is the variance of the covariate for the $k$ th category. Similar to case with ANOVA, the null hypothesis for Levene's test is also tested with $\alpha \%$ level of significance. If the null hypothesis is rejected, then it is said that the variances are not homogenously distributed across the categories.

About the post-hoc tests, if a covariate had variances homogeneously distributed according to the result of Levene's test, then Least Significant Difference (LSD) test would be conducted. On the other hand, if the variances had heterogeneous distribution across the mode alternatives, then Tamhane $\mathrm{T} 2$ test would be applied. In this study, all tests were conducted with $5 \%$ level of significance ( $95 \%$ level of confidence).

\section{Results}

\subsection{Istanbul Atatürk International Airport}

As it was also explained in the previous section, Levene's test was applied to all covariates to understand if the variances were distributed homogeneously. Levene's test statistics in Table 4 indicated that hypothesis of the homogeneity of variances for all covariates can be rejected at $5 \%$ level of significance. Hence, in case of the rejection of null hypothesis of equal means in ANOVA, Tamhane's T2 test would be applied as the post-hoc test instead of LSD test for all variables. 
Table 4: Levene's test for covariates for IST.

\begin{tabular}{ccc}
\hline & $\begin{array}{c}\text { Levene } \\
\text { Statistic }\end{array}$ & p-value $^{1}$ \\
\hline Age & 3.513 & 0.015 \\
Group Size & 3.912 & 0.009 \\
Margin & 6.220 & 0.000 \\
Number of Luggage & 5.443 & 0.001 \\
Cost & 43.532 & 0.000 \\
Travel Time & 2.991 & 0.031 \\
\hline
\end{tabular}

${ }^{1}$ Significance level: 0.05

The next analysis was ANOVA. In Table 5, ANOVA test results showed that no covariates had statistically equal mean values across the mode types, except Number of Luggage. Its p-value is 0.268 , and larger than the $5 \%$ level of significance. Thus, it can be said that Number of Luggage is not affecting mode choice; and should not be included in any discrete mode choice model for airport access behavior. This result contradicts [1] and [4]; and hence, raises a question about the transferability of the mode choice models for airport access.

Table 5: ANOVA for the covariates between the mode types for IST.

\begin{tabular}{ccccc}
\hline & & MS $^{1}$ & F-statistic & p-value \\
\hline Age & BG $^{2}$ & 1271.644 & 8.977 & 0.000 \\
& WG $^{3}$ & 141.653 & & \\
Group & BG & 12.887 & 4.501 & 0.004 \\
Size & WG & 2.863 & & \\
& BG & 50312.648 & 5.789 & 0.001 \\
Margin & WG & 8690.569 & & \\
Number & BG & 1.212 & 1.318 & 0.268 \\
of & WG & 0.920 & & \\
Luggage & BG & 42664.281 & 38.860 & 0.000 \\
Cost & WG & 1097.891 & & \\
Travel & BG & 10665.440 & 10.758 & 0.000 \\
Time & WG & 991.404 & & \\
\hline
\end{tabular}

${ }^{1}$ Mean Square

${ }^{2}$ Between Groups

${ }^{3}$ Within Groups

${ }^{4}$ Significance level: 0.05

At least two modes had different mean values for the remaining five covariates, which meant that post-hoc tests would be carried out. Previously, Table 4 showed that variances were not homogeneous for the covariates. Therefore, Tamhane T2 post-hoc test was applied for Age, Group Size, Margin, Cost and Travel Time variables.

Tamhane T2 test results are given in Table 6 . The inferences about similarities were made in $5 \%$ level of significance. Statistics were given only for the modes which showed statistical similarity. Estimated mean difference (EMD) should be interpreted as follows: It is the difference of the means between the modes in the first column and the second column. It should be noted that the difference is found by subtracting the mean in the second column from the one in the first column. Negative sign for the EMD indicates that mean of the mode in the first column is smaller.

In terms of Travel Time, auto and drop-off modes were similar to all other modes, but PT and taxi were not similar to each other. Both were similar to auto and drop-off modes separately. It can be understood that passenger who opted for PT mode spent the longest travel time, and taxi users spent the shortest travel time to arrive IST. However, these abundant similarities cannot be found for Cost, only auto and taxi modes had similar travel costs to IST. This is logical because dropoff is of zero cost for a passenger and public transport is much cheaper than auto or taxi.

Furthermore, some of the modes had similar means of Margin values. Auto was similar to all other modes except PT with respect to this variable, while PT mode was similar to only taxi. Passengers leave a larger time margin for their airport trips if they expect longer travel times. Hence, similarities between PT and taxi in terms of Margin could mean that passengers either arrived IST from farther origin points using rail transit or taxi; or expected to be delayed in congestion during their taxi rides. The shortest time margin was observed in auto trips.

Group Size and Age were similar between all modes except PT. PT was similar to only drop-off mode. It can be observed in Table 6 that PT had the least mean value of group size among all modes, which meant that larger groups avoided rail transit to access IST. Further, PT also had the lowest age mean. Considering the fact that surveys included passengers who were above 18 years of age, younger people opted for PT to access IST. On the other hand, age mean was the highest for taxi users. This is logical because elderly may choose taxi for comfortable trips. It can be said that these two variables had a direct effect on choice of public transit to IST. 
Table 6: Post-hoc tests of the covariates between modes for IST.

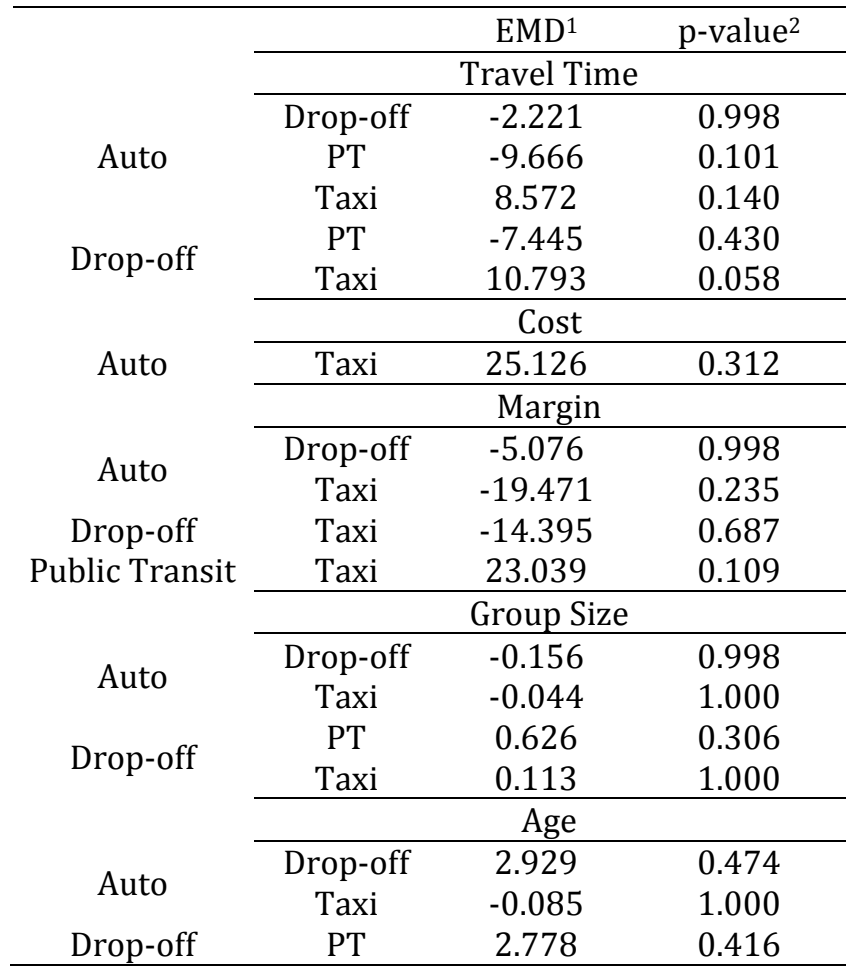

${ }^{1}$ Estimated Mean Difference

${ }^{2}$ Significance level: 0.05

\subsection{Sabiha Gokcen International Airport}

The case of SAW airport is different than of IST. Levene's test statistics in Table 7 indicated that hypothesis of the homogeneity of variances cannot be rejected at 5\% level of significance for two of the six covariates: Travel Time and Number of Luggage. Hence, LSD test would be applied for these two variables, and the remaining would have Tamhane T2 test for posthoc; if only they did not have equal means across the modes in ANOVA.

Table 7: Levene's test for covariates for SAW.

\begin{tabular}{ccc}
\hline & $\begin{array}{c}\text { Levene } \\
\text { Statistic }\end{array}$ & p-value $^{1}$ \\
\hline Age & 5.189 & 0.000 \\
Group Size & 2.513 & 0.042 \\
Margin & 4.496 & 0.002 \\
Number of Luggage & 0.800 & 0.526 \\
Cost & 52.164 & 0.000 \\
Travel Time & 2.216 & 0.068 \\
\hline
\end{tabular}

${ }^{1}$ Significance level: 0.05

In Table 8, ANOVA test results showed that, like in the IST case, Number of Luggage is not affecting mode choice, since it has a significance value of 0.514 . However, a major difference between SAW and IST was revealed. That is, unlike IST case, Group Size and Age did not have an effect on mode choice to access SAW. This is because their significance values were larger than 5\% level of significance; and thus, have equal means across the modes. This result is also contradictory to other studies ([3], [11], [13], [14]) as well as the case of IST. Not only does this raise a question about transferability in general, it shows that mode choice patterns between IST and SAW are different. On the other hand, other covariates had significance values lower than the significance level of $5 \%$, hence, at least two modes had different means of those other covariates.

Table 8: ANOVA for the covariates between the mode types for SAW.

\begin{tabular}{ccccc}
\hline & & MS $^{1}$ & F-statistic & p-value $^{4}$ \\
\hline Age & BG $^{2}$ & 253.483 & 2.198 & 0.070 \\
& WG $^{3}$ & 115.322 & & \\
Group & BG & 1.810 & 1.712 & 0.148 \\
Size & WG & 1.058 & & \\
& BG & 38215.682 & 14.398 & 0.000 \\
Margin & WG & 2654.315 & & \\
Number & BG & 0.628 & 0.820 & 0.514 \\
of & WG & 0.765 & & \\
Luggage & BG & 39625.827 & 204.269 & 0.000 \\
Cost & WG & 193.988 & & \\
Travel & BG & 15873.487 & 15.253 & 0.000 \\
Time & WG & 1040.648 & & \\
\hline
\end{tabular}

${ }^{1}$ Mean Square

2Between Groups

${ }^{3}$ Within Groups

${ }^{4}$ Significance level: 0.05

LSD and Tamhane T2 test results are given in Table 9. As explained before, LSD test was applied only on Travel Time and Tamhane T2 test on Cost and Margin. Again, the inferences about similarities were made in $5 \%$ level of significance.

In terms of Travel Time and Margin, auto, taxi and dropoff modes were similar to each other, but PT and shuttle services were not similar to those three covariates; they form similarity between themselves. This could be expected because passengers who preferred PT or shuttle spent more time to access SAW, and hence spared more time margin; as those modes are slower.

As for Cost, none of the estimated means of modes were similar to each other; they were all different from each other. For other covariates, only the similarities were shown in Table 9; but since no similarity found for Cost variable, all dissimilarities were shown for clarity. This result is also interesting, because these dissimilarities were not found in the IST case; in which auto and taxi costs were similar. However, they were different in SAW case; this could be because SAW is $42 \mathrm{~km}$ far from Istanbul city center, farther than IST is. So, passengers who had chosen taxi might have arrived from longer 
distances, paid higher fees, as mean taxi cost was revealed to be greater than mean auto cost.

Table 9: Post-hoc tests of the covariates between modes for SAW.

\begin{tabular}{|c|c|c|c|}
\hline \multirow{4}{*}{ Auto } & & EMD $^{1}$ & p-value ${ }^{2}$ \\
\hline & \multicolumn{3}{|c|}{ Travel Time } \\
\hline & Drop-off & 4.059 & 0.622 \\
\hline & Taxi & 11.788 & 0.127 \\
\hline \multirow{3}{*}{$\begin{array}{c}\text { Drop-off } \\
\text { Public Transit }\end{array}$} & Taxi & 7.729 & 0.259 \\
\hline & Shuttle & -2.360 & 0.675 \\
\hline & \multicolumn{3}{|c|}{ Margin } \\
\hline \multirow{2}{*}{ Auto } & Drop-off & -8.340 & 0.999 \\
\hline & Taxi & -2.799 & 1.000 \\
\hline \multirow{4}{*}{$\begin{array}{c}\text { Drop-off } \\
\text { Public Transit }\end{array}$} & Taxi & 5.541 & 0.999 \\
\hline & Shuttle & 25.628 & 0.141 \\
\hline & & Cost & \\
\hline & Drop-off & 38.667 & 0.000 \\
\hline \multirow{4}{*}{ Auto } & Public Transit & 33.667 & 0.000 \\
\hline & Shuttle & 26.397 & 0.000 \\
\hline & Taxi & -28.301 & 0.000 \\
\hline & Public Transit & -5.000 & ----- \\
\hline \multirow[t]{2}{*}{ Drop-off } & Shuttle & -12.270 & 0.000 \\
\hline & Taxi & -66.969 & 0.000 \\
\hline \multirow{2}{*}{ Public Transit } & Shuttle & -7.270 & 0.000 \\
\hline & Taxi & -61.969 & 0.000 \\
\hline Shuttle & Taxi & -54.698 & 0.000 \\
\hline
\end{tabular}

${ }^{1}$ Estimated Mean Difference

${ }^{2}$ Significance level: 0.05

\section{Discussion and Conclusion}

In this study, the covariates affecting the airport access mode choice to IST and SAW have been investigated. It was aimed to understand if the variables had an effect on mode choice to access to IST and SAW separately, and it was observed that the effects are different between the two airports. Even though IST is now closed for passenger flights, this study can be valuable for comparison purposes of airports in terms of ground access mode choices and policy developments for other airports, especially for the recently opened Istanbul Airport.

Out of six candidate covariates, five of them were revealed to be affecting the mode choice to access IST while that number was only three for SAW. Only travel time, travel cost to SAW and time margin influenced mode choice. This finding should be considered as a major difference between the mode choice mechanisms to access these airports.

On the other hand, the two airports show several similarities in terms of the effects of variables. Number of luggage that the passengers carry did not have any significant effect on airport access mode choice. In addition, travel time and time margin affect the mode choice for access to both IST and SAW.

The results are also important for policy making. Decision makers can make use of this study's results for policy developments for the ground access to recently opened Istanbul Airport. The policies regarding modes to access for the two airports might be different because of the differences in affecting covariates. For example, number of luggage has no effect on mode choice to access SAW or IST. Since the public transit for SAW is made of public buses, luggage racks and small size flight information screens can be installed in the buses serving SAW. Furthermore, the schedule of bus services can be adjusted to the peak hours of air traffic at SAW. Shuttle services may not need a luggage rack because they already have a hold under the vehicles; but can benefit from flight information screens like public buses. Similarly, their frequencies can be increased during the peak hour of air traffic. IST is now closed; however, the flight information might be given along the stations of the semi-rapid transit line serving airports like IST. Also, the luggage racks might be installed in the rail cars. Furthermore, both Istanbul Airport and SAW are expected to receive rail service in the future. Therefore, these policy recommendations regarding rail services might be implemented for these airports in the future.

The findings of this study reveal the questionable status of transferability of potential mode choice models for airport access. Therefore, in future work, this situation should be considered for developing mode choice models for airports.

\section{Acknowledgment}

The author would like to thank Assoc. Prof. Ilgin Gokasar for her contributions.

\section{References}

[1] Harvey, G., "Study of Airport Access Mode Choice", Journal of Transportation Engineering, 112 (5), 525$545,1986$.

[2] Akar, G., "Ground access to airports, case study: Port Columbus International Airport", Journal of Air Transport Management, 30, 25-31, 2013.

[3] Tam, M. L., Lam, W. H., \& Lo, H. P., "Modeling air passenger travel behavior on airport ground access mode choices", Transportmetrica, 4 (2), 135-153, 2008.

[4] Choo, S., You, S., \& Lee, H., "Exploring characteristics of airport access mode choice: a case study of Korea", Transportation Planning and Technology, 36 (4), 335-351, 2013.

[5] Alhussein, S. N., "Analysis of ground access modes choice King Khaled International Airport, Riyadh, Saudi Arabia", Journal of Transport Geography, 19 (6), 1361-1367, 2011.

[6] Yang, C. W., \& Liao, P. H., "Modeling the joint choice of access modes and flight routes with parallel structure and random heterogeneity", Transp. Res. Part E: Logist. Transp. Rev., 95, 19-31, 2016.

[7] Jou, R-C., Hensher, D. A., \& Hsu, T-L "Airport ground access mode choice behavior after the introduction of a new mode: A case study of Taoyuan International Airport in Taiwan", Transp. Res. Part E Logist. Transp. Rev., 47 (3), 371-381, 2011.

[8] Monteiro, A. B. F., \& Hansen, M., "Improvements to airport ground access and behavior of multiple 
airport system: BART extension to San Francisco International Airport", Transportation Research Record, 1562, 38-47, 1996.

[9] Hess, S., \& Polak, J. W., “Airport, airline and access mode choice in the San Francisco Bay area", Papers in Regional Science, 85 (4), 543-567, 2006.

[10] Pels, E., Nijkamp, P., \& Rietveld, P., "Access to and competition between airports: A case study for the San Francisco Bay area", Transp. Res. Part A Policy Pract., 37 (1), 71-83, 2003.

[11] Koster, P., Kroes, E., \& Verhoef, E., "Travel time variability and airport accessibility", Transportation Research Part B: Methodological, 45 (10), 1545-1559, 2011.

[12] Gokasar, I., \& Gunay, G. "Mode choice behavior modeling of ground access to airports: A case study in Istanbul, Turkey", Journal of Air Transport Management, 57, 1-7, 2017.

[13] Gupta, S., Vovsha, P., \& Donnelly, R. M., “Air Passenger Preferences for Choice of Airport and Ground Access Mode in the New York City Metropolitan Region", Transportation Research
Record: Journal of the Transportation Research Board, 2042 (1), 3-11, 2008.

[14] Budd, T., Ryley, T., \& Ison, S., "Airport ground access and private car use: a segmentation analysis", Journal of Transport Geography, 36, 106115, 2014.

[15] Tsamboulas, D. A., \& Nikoleris, A., "Passengers' willingness to pay for airport ground access time savings", Transp. Res. Part A Policy Pract., 42 (10), 2008.

[16] Budd, T., Ison, S., \& Ryley, T., "Airport surface access in the UK: A management perspective", Research in Transportation Business and Management, 1 (1), 109-117, 2011.

[17] Walpole, R. E., Myers, R. H., Myers, S. L., \& Ye, K., Probability \& Statistics for Engineers and Scientists, Pearsons Education International, Upple Saddle River, 2007. 